\title{
複数の案内ロボットが連携してサービス提供する ネットワークロボットシステムの実現
}

\author{
塩見昌裕*1 神田崇行*1 Dylan F. Glas*1 \\ 佐 竹聡*1 石 黒浩*1*2 萩 田 紀 博*1
}

\section{A Network Robot System for Cooperative Guide Service in a Shopping Mall}

\author{
Masahiro Shiomi*1, Takayuki Kanda*1, Dylan F. Glas*1, \\ Satoru Satake*1, Hiroshi Ishiguro*1*2 and Norihiro Hagita*1
}

\begin{abstract}
In this paper, we report a field trial with a network robot system in a shopping mall. Our network robot system consists of three components: environmental sensors, network robot platform and social robots. Multiple laser range finders are used as the environmental sensors to estimate people's positions. Position data is used to estimate such human walking behaviors as "stopping" or "idle walking," to direct robots to provide appropriate tasks to appropriate people. By using this information, the network robot platform coordinates multiple social robots to provide efficient service to customers. It coordinates the tasks of robots based on their positions and people's walking behavior, the paths of robots, and the conversation-performance between two robots. Each social robot interacts with people to provide recommendation information about shops and route information of the mall. The system sometimes simultaneously uses two robots to lead people from one place to the specific shop. We conducted a field trial in a shopping mall, in which four robots interacted with 414 people. It demonstrated the effectiveness of the network robot system for guiding people around a shopping mall as well as increasing their interest.
\end{abstract}

Key Words: Network Robot, Communication Robot, Shopping Mall, Field Trial

\section{1. は じめに}

商業施設や駅構内などの日常環境における, 人々に道案内や 情報提供などのサービスを提供する新たなデバイスとして，コ ミュニケーションロボットの研究開発が進んでいる。これまで にも, 博物館での案内ロボット [1] [2] や, 大学構内での受付ロ ボット [3], 小学校での語学学習支援ロボット [4], 病院や家庭な どの施設におけるへルスケアロボット $[5] 〜[7]$ など, 様々な研 究開発が行われている.

さらに，このようなロボットが複数台で連携して活動するこ とで, 状況に応じてサービスを行うロボットを切り替えること や, サービス内容そのものを切り替えることが可能になる. 例 えば広大な商業施設のような, 人々が道に迷いやすく, 頻繁に 地図が利用される環境では, あるロボットは地図の前で待ち受 け, 訪れた人々に道案内を行っている際に, 別のロボットは地

原稿受付 2010 年 5 月 26 日

*1国際電気通信基礎技術研究所

$* 2$ 大阪大学

${ }^{* 1}$ ATR

${ }^{* 2}$ Osaka Univ.

口本論文は提案性で評価されました。
図から離れた場所で巡回を行い, 自ら人々へ近づいて道案内を 提供する，といった連携が可能になる。また，実際の店舗で人 間が行っているように，特定の店舗前へ誘導する役割と店舗前 で説明する役割を 2 台のロボットが分担して行うといった連携 が可能になる。そそような連携を実現するために，我々は，複 数のロボットが同一環境下で連携してサービスを提供するため の, ロボット間の調整を行う枠組みが必要不可欠であると考え る，例えば，人々の位置や行動に応じてサービスを提供するた めに必要なタスク（巡回する，人にアプローチする，対話を開 始する，など）を実行するロボットの切り替え，タスクに応じ た各ロボットの移動経路を調整，タスク連携を行うロボットの 決定，といった仕組みが必要になるであろう。

これまでにも, 複数ロボットが連携して主に環境内の地図を 効率的に作成するシステム [8] や，ロボットサッカーのアプリ ケーションを題材にロボット間の移動経路や役割を決定するシ ステムの開発 [9] は行われてきた。 また, 科学博物館 $[1]$, 万博 会場 [2], 商業施設 [10] といった，一般の人々が行き交う環境で の情報提供サービスを行う個別のロボットシステムも開発され ている。ささらに, 家庭内やオフィス内といった，比較的静的な 環境において，ロボットが連携してサービス提供を行うシステ 


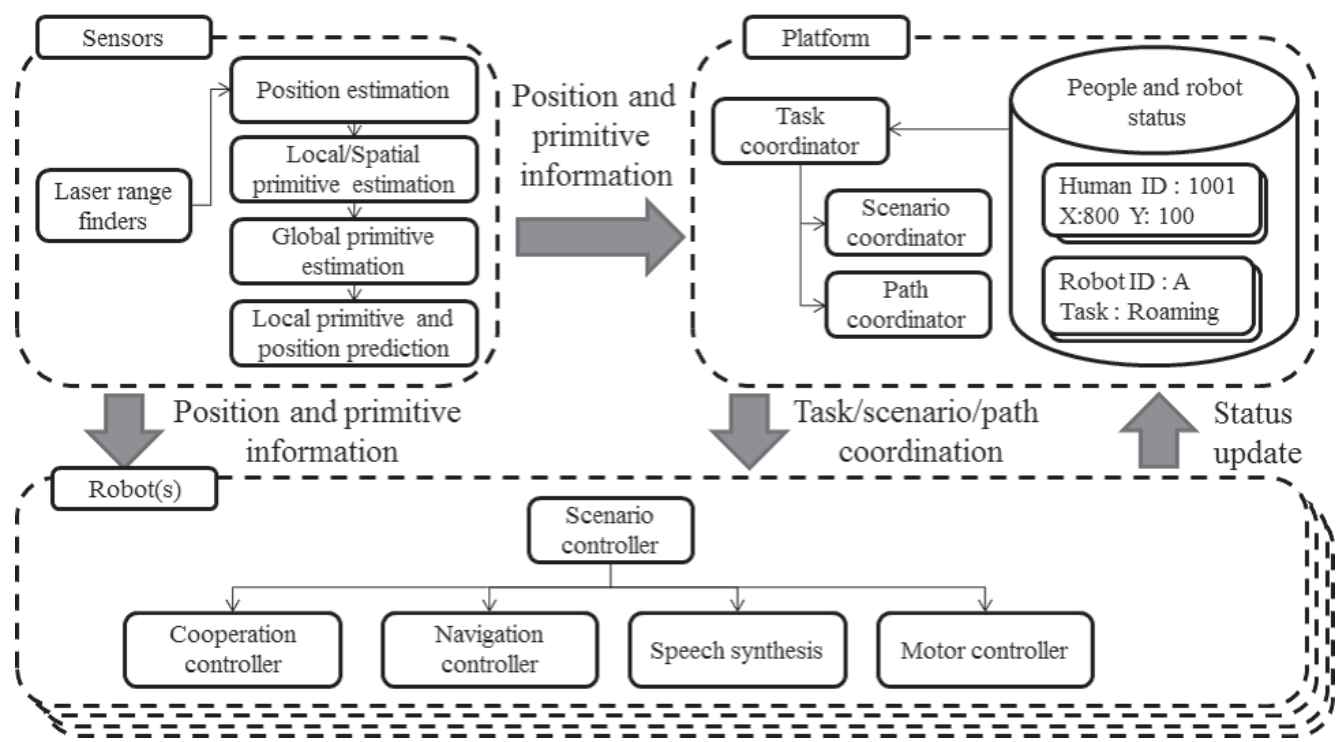

Fig. 1 Overview of the networked robot system

ムも開発されている [5] [11].しかしながら，これらの研究では， 一般の人々が行き交う動的な環境下で，複数のロボットが連携 してサービスを提供するシステムを実現するために，どのよう な枠組みに基づいてロボットが活動をすべきか, といった問題 は取り組まれていなかった。

本研究では, 商業施設のような日常環境において, 複数ロボッ トが連携してサービス提供を実現するためのシステム開発を行 う. 開発するシステムは, 人々の行動を観測するために設置さ れた環境センサ，複数存在するロボット間の役割や移動経路を 状況に応じて調整するプラットフォーム, および人々にサービ ス提供を行う複数のロボットから構成される。本稿では, 商業 施設内で複数のロボットが連携して店舗推薦や道案内, 特定店 舗への誘導などを行うための一連のシステム開発と，それをも とに一般の人々へのサービス提供を行うフィールド実験につい て報告し，開発したシステムの有効性を示す。

\section{2. システムの設計指針}

\section{1 ネットワークロボットシステム}

同一環境内で複数のロボットが連携してサービスを提供する ために, 我々は, 各ロボットのタスク・移動経路・連携シナリ オの, 3 種類の調整を行う必要があると考える。これらの調整 を実現するために，環境中のセンサから観測される人々の情報 に基づき, 中央システムが各ロボットの状況や位置に応じて役 割や移動経路を効率的に調整する, ネットワークロボットとよ ばれるアプローチが注目されている $[12]$.

我々も，このような中央システムを用いることで，複数ロボッ 卜間の連携を実現する。例えば，人々やロボットの位置関係の 変化などの状況に応じてロボット間でタスクを調整することで, 1 人のユーザに複数のロボットが同時に情報提供を行う，何度も 同じユーザに各ロボットが情報提供を行う, 等の不自然な状況 を防ぐことができる，また，移動経路の調整を夕スクの優先度 や人々・ロボットの位置を考慮して行うことで，ロボットは互い
に邪魔をせずに人々へ近づくことや，特定の場所へ移動するこ とができる。ささらに，連携シナリオを調整して 2 台のロボット が物理的に協調し，タイミングを調整して振る舞うことで，ロ ボット間でのタスク分担や連携を行う。

このような, 各ロボットのタスクや移動経路, 連携シナリオ の調整を実現するためには，環境中に存在する人々やロボット の位置情報を精度よく取得する必要がある。ロボット単体のセ ンシング能力はいまだ限られているため, 我々は環境側にセン サを設置することでそのセンシング能力を補う手法を用いる.

これらの考察に基づいて我々が提案する，ネットワークロボッ トシステムの概要図を Fig. 1 に示す。ネットワークロボットシ ステムは，1．環境センサ，2．ネットワークロボットプラット フォーム，3. ロボット，の 3 要素から構成される． 3 章以降で, 各要素に関する実装の詳細について記述を行う。

\section{2 ロボットのタスクデザイン}

日本政府のレポート [13]によると, 人々が日常環境下におい てロボットに求めている役割として, 商業施設や駅などの公共 空間における情報提供サービスが報告されている。また，荷物 を運搬するなどの，物理的なサービスも同様に求められている と報告されている.

これらの報告をもとに, 我々は多くの店舗が存在する商業施 設内において，道案内や店舗に関する情報提供を行う「案内口 ボット」として商業施設に導入されるシナリオを想定してロボッ トのタスクをデザインした。具体的には，ロボットの役割とし て, 地図の前や特定店舗の前であらかじめ待ち受けて情報提供 を行うものと, 環境中を巡回しつつ人々の行動予測に基づいて アプローチを行い情報提供するというものの，大きく 2 種類を 設定する。人々と対話を開始して情報提供を行う際には，道案 内と特定店舗への誘導に関するオファーを行い，人々が望んた 情報の提供を行う。人々が特定店舗への誘導を望んだ場合に，あ らかじめ特定店舗の前で待ち受けているロボットがアイドル状 態であった場合には，そのロボットとの連携を行い店舗への誘 
導と情報提供を行う。

タスクの詳細と, 各タスクがどのようにロボットへとアサイ ンされるかのルールは，4.1節に記述する.

\section{3. 環境センサシステムの実装}

本章では，4章で記述するネットワークロボットプラットフォー ムがロボットのタスクを決定するために用いられる, 人々の行動 やロボットの位置情報を推定する環境センサシステム（Fig. 1, 左上）の具体的な実装内容について記述する。 人々の位置情報 は「止まっている」「ゆっくり歩いている」「走っている」など の, 移動軌跡に基づく局所的な移動行動（以下, 局所行動と記 述）や，「地図の前」「店舗の前」などの場所に関する情報（以 下，空間行動と記述）を推定するために用いられる. さらに, こ れらの軌跡情報を蓄積することで，「環境内をゆっくり通過す る」「店舗の前で立ち止まる」などの大局的な移動行動（以下， 大局行動と記述）を推定する [14].

\section{1 人位置推定}

我々は，人々の位置を推定するためのセンサとして，6 台の レーザレンジファインダー（LRF），SICK LMS-200 を環境内 に設置する，センサの高さは，85[cm] とした，実際にセンサを 設置した環境の外観と，センサを Fig. 2 に示す.

各センサから得られた距離情報を統合して人々の位置を推定 するために, Dylan らによって開発されたアルゴリズムを用い た[15]. 手法の詳細は文献 [15] に示すが, パーティクルフィル 夕を用いて, 腰の高さで計測された環境内の距離データと形状 デー夕から個人の位置推定を行っている. 平均的な歩行速度を 想定した場合には，位置推定誤差は $+/-6[\mathrm{~cm}]$ の誤差であった.

\section{2 局所行動}

局所行動とは，人々の局所的な移動行動，例えば「歩いてい る」「止まる」などを分類したものである [14]. 本研究では，局 所行動を「早く歩く」「うろう万する」「ゆっくり歩く」「止ま る」という四つに分類した.

本システムでは，サポートベクターマシン（SVM）[16] とよ ばれる学習機を用いることで, 移動量や移動速度, 移動軌跡の特 徵量からこれらの局所行動を動的に推定する.SVM を学習する 軌跡データを作成するために, ショッピングモールを実際に訪れ た訪問客の軌跡を手動で分類した．最終的に 701 個のデー夕に対 してラベリングを行い, leaving-one-out method を用いて判別

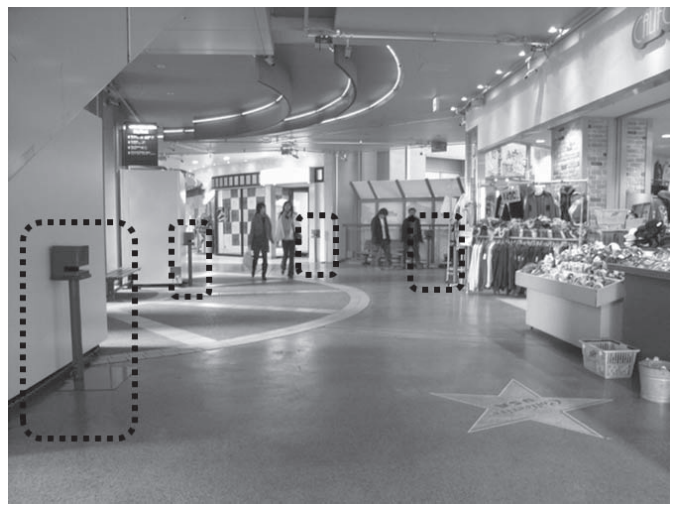

Fig. 2 Shopping arcade and laser range finders
佐 竹聡石黒浩萩田紀博

性能を検証した結果, 平均推定成功率は $90 \%$ 以上であった [14].

\section{3 空間行動}

空間行動とは, 店舗前やベンチ, 地図の前など, 特定の場所 に関する情報を定義したものである。これらの判定は, 人々の XY座標から行われる。 この空間行動を用いることで, 例えば 地図の前で止まっている人にのみ道案内サービスを提供するな どの, 人々の場所に応じたロボットサービスを実現する. 本研 究では, 人々へ提供すべきサービスが変化する場所として, 空 間行動を「地図の前」「店舗の前」「通路」の三つに分類した。

\section{4 大局行動}

大局行動とは，「左側から右側へ環境内をゆっくりと通過す る」「店舗前までゆっくりと歩いてきたあとに，店舗に入る」な どの, 空間の利用状況や人々の行動パターンを意味する行動を 定義したものである。環境内での大局行動を解析するために， 我々は過去に開発されたアルゴリズムを用いて，1 万人以上の 移動軌跡の解析を行った。この手法では，大局行動はグリッド 上に分割された各空間における局所行動の遷移によって表現さ れる。蓄積された移動軌跡から特徵量を取得し, k-means 法に 基づく軌跡のクラスタリング法 [14] を利用することで，大局行 動を軌跡群のクラスタとして抽出する。手法の詳細は文献 [14] に示すが，DP マッチングにより軌跡の比較を行うことで類似 度の計算を行い, クラスタリングを行っている.

最終的に 300 の典型的な大局行動を意味するクラス夕を得る ことができ，そのうちいくつかは忙しい人間のパターンを示し た（Fig.3(a)）。またくつかは，ウインドウショッピングの パターンを示した（Fig. 3(b)). Fig. 3 において色の濃い箇所 は, そのクラスタに分類された軌跡が頻繁に通過する場所を示 す。また色の薄い箇所は, そのクラス夕に分類された軌跡が通 る頻度の低い場所を示す.

\section{5 局所行動と位置の予測}

解析された大局行動の情報と, 環境センサから観測された人々 の移動軌跡を用いることで, 大局行動を推定し, 数秒後に起き る可能性の高そうな局所行動とその位置を予測する。行動と位 置の予測は, 観測されたすべての人間に対して行われる [14]. 詳 細は文献 [14] に示すが, 観測開始から $\mathrm{T}$ 秒経過した人間の行動 を予測する場合, その軌跡と類似する複数クラス夕の平均軌跡 の， 最初の $T$ 秒間に対して DP マッチングによる比較を行うこ とで，最も類似した五つのクラスタを選択する。それらのクラ スタから予測される $T+t$ 秒における局所行動と位置を計算し, 局所行動と位置の総出現頻度を予測する.

Fig. 4 に, ある人間の行動予測結果を示す.太線で描かれた 丸が，人間の位置を示している。予期された軌道は，廊下を左 下から右上へと移動するものであり，システムが人間の移動軌

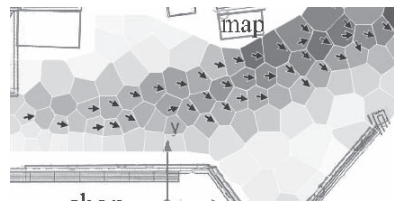

(a) A "busy person" pattern

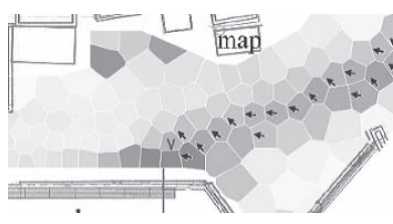

(b) A "window shopper" pattern
Fig. 3 Extraction of typical behaviors 
Table 1 Tasks and path priorities

\begin{tabular}{|c|c|c|c|}
\hline Task & Contents & Task priority & Path priority \\
\hline Roaming & Roam around (allowed to be assigned below tasks) & 7 & 6 \\
\hline Approach to a person & Approach to a person who does idle walking or stop & 6 & 1 \\
\hline Guide to the shop & $\begin{array}{c}\text { Guide a person who wants to visit to the shop. } \\
\text { (If possible, two robots collaborate with each other to do this task) }\end{array}$ & 2 & 2 \\
\hline Stand-by at the map & Wait at the front of the map & 3 & 4 \\
\hline Stand-by at the shop & Wait at the front of the shop & 5 & 4 \\
\hline Stand-by at the charging point & Wait at the charging point & 1 & - \\
\hline Interaction & $\begin{array}{c}\text { Provide recommendation information } \\
\text { about shopping and/or route guidance }\end{array}$ & & \\
\hline
\end{tabular}

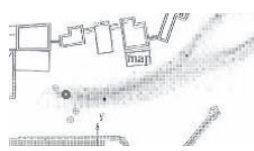

(a) $t+5$

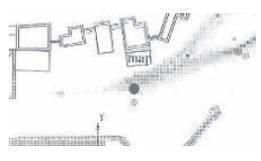

(b) $t+10$

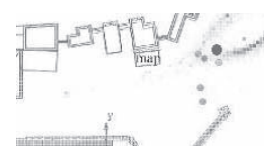

(c) $t+15$
Fig. 4 Example of prediction of future local behavior

跡を予測できたことが示されている.

\section{4. ネットワークロボットプラットフォームの実装}

ネットワークロボットプラットフォーム（Fig. 1, 右上）は, 環境センサから得られる人々やロボットの位置情報, タスクの 実行状況に基づいて, 複数ロボット間のタスクや移動経路, 連 携シナリオという 3 種類の調整を行う。例えば, 人々が道に迷 いやすく, 頻繁に地図が利用されるような環境では, あるロボッ トが地図の前で待ち受けて道案内サービスを提供しつつ, 別の ロボットは環境中を巡回して人々へ道案内サービスを提供する といった，状況や環境に応じたロボット間連携を実現する。ま た, 実際の商業施設内で人間が行っているような, 特定店舗前 へと誘導する役割と店舗前で説明する役割を 2 台のロボットで 分担するためのタスク連携に関する調整も行う，以下に，各調 整機構の機能について記述する.

\section{1 タスク調整機構（Task coordinator）}

タスク調整機構は, 環境センサから推定された人々の位置や 行動, 人々やロボットの位置, およびロボットの内部状態という 三つの要素を考慮してタスクを調整する。また, どの人物にど のタスクが行われたかの履歴を用いることで, 同じ人物に何度 もアプローチを行う, 複数のロボットが同時にアプローチを行 うといった不自然なタスクアサインを回避する。ロボットが行 うタスクと, そのタスクをアサインするルールを, Table 1 に 示す (priorityの值は, 1 が最も優先度が高いことを意味する).

ローミング： 本タスクは，アイドル状態のロボットが環境 内を巡回するために用いられる。 タスクがアサインされていな いロボットに対して, 環境内に人々が存在しない場合や, 存在 する人々の予測された局所行動が「早く歩く」であった場合に は，このタスクがアサインされる。このタスクがアサインされ たロボットは，ローミングタスク用の移動経路に従って環境内 を移動する.

アプローチ： 本タスクは，サービスを提供する対象に，ロ ボットから近づくために用いられる，具体的には，ローミング タスクがアサインされているロボットに対して, 環境内に存在
する人の予測された局所行動が「ゆっくり歩く」「止まる」で あった場合で，ロボットの移動速度と人・ロボット間の距離を考 慮してアプローチが可能であった場合に, このタスクがアサイ ンされる，アサインされたロボットは, 後述するアプローチ用 の移動経路に従って対象となるユーザにアプローチを行う。ア プローチ中に，ユーザが立ち去るなどの理由によってロボット の距離が離れ，アプローチが困難と判断された場合には，アプ ローチタスクを終了させる。なお，アプローチタスクを割り当 てられたロボットが人にアプローチする際には, ロボットは対 象に視線を向けるなど対話意図を対象に伝えながら接近するよ うに設計した [17].

なお, アプローチタスクにおける移動経路の優先度は, 対象 への到達時刻を短くするために, 最も高い值とした。また, 一 度アプローチを行った人物や, 現在アプローチ対象となってい る人物は,アプローチの対象とならないように設計した。これ は, 複数のロボットが同じ人物に何度もアプローチを行わない ようにするためである。

店舗への誘導：本タスクは, 人々を店舗へ誘導して情報提 供を行うために用いられる。対話タスクを行っているロボット に対して，人々が店舗への誘導を望んだ場合には，対話タスク が終了され，このタスクがアサインされる。アサインされたロ ボットは, 人々と店舗前まで一緒に移動して, 店舗の説明を行 う。なお，このタスクがアサインされたときに，店舗前での待 ち受けタスクを行っているロボットが存在した場合には, 2 台 のロボットによる連携が行われる。詳細は 4.3 節に記述するが, これら 2 台のロボットは連係動作を開始し, 店舗への誘導と説 明という役割をロボット間で分担して行う.

地図前での待ち受け：本夕スクは，人々が立ち止まりやす い地図の前で待ち受けて, 道案内に関する情報提供を求める人 たちに効率的に話しかけるために用いられる。このタスクがど のロボットにもアサインされていない状態で, 地図近辺で対話 タスクを行っているロボットが存在しなければ, 最も地図に近 く，かつローミングタスクがアサインされているロボットにタ スクがアサインされる。このタスクがアサインされるロボット の数は, 最大 1 台である.アサインされたロボットは, 地図前 へ移動を開始し, 待ち受けを行う.

店舗前での待ち受け：本タスクは，店舗前でロボットが待ち 受けることで, 店舗に興味を持った人に効率的に話しかけるた めに用いられる。このタスクがどのロボットにもアサインされ ていない状態で, 店舗前近辺で対話夕スクを行っているロボッ トが存在しなければ, 最も店舗に近く, かつローミングタスク 
がアサインされているロボットにタスクがアサインされる。こ のタスクがアサインされるロボットの数は, 最大 1 台である アサインされたロボットは，店舗前へ移動を開始し，待ち受け を行う。

バッテリー充電： 本タスクは, 各ロボットの活動時間を効率 的に延長させ, 複数台のロボットによるサービス提供が可能な 時間を増加させるために用いられる。ローミングタスクがアサ インされているロボットに対して, バッテリー残量が一定未満 になった場合に、このタスクがアサインされる。タスクをアサ インされたロボットはバッテリーを充電する場所まで移動を開 始し，バッテリーの交換が終了するまで待機する。 バッテリー の交換が終了し, バッテリー残量が一定以上になって移動可能 になった場合に，バッテリー充電タスクを終了させる。この夕 スクがアサインされるロボットの数は, 最大 1 台である.

対話： 本夕スクは，ロボットが人々との対話を開始する際 に用いられる。対話タスクは，アプローチタスクがアサインさ れたロボットがアプローチ対象に $1[\mathrm{~m}]$ 以内に近づいた場合と, 待ち受けタスクがアサインされたロボットの周囲 $1[\mathrm{~m}]$ で人々の 局所行動が「止まる」と予測された場合に，そのロボットへア サインされる。また，人がロボットに話しかけた場合には，こ のタスクが最優先でアサインされる。このタスクでは，対象と なるユーザに対して挨拶を行ったあと, 道案内と特定店舗への 誘導に関するオファーを行い，人々が望んだ情報の提供を行う. 対話が終了した場合や, 対話途中でユーザが立ち去った場合に は，対話タスクは終了し，ローミングタスクがアサインされる. 対話中に人々が店舗への誘導を望んだ場合にのみ, 上述した店 舗への誘導タスクがアサインされる.

\section{2 移動経路調整機構（Path coordinator）}

移動経路調整機構は，タスクをアサインされたロボットが，夕 スクを実行するために必要とする移動経路を計算する。移動経 路は, ロボットの速度から計算される安全停止距離を考慮して 計算され，ロボットがすれ違う場合に衝突が起きないように設 定される. Fig. 5 に, 移動経路の計算結果例を示す. 三角の記 号がロボットの位置を示しており, そこから延びる線が移動経 路を意味している。この例では，2台がそれぞれ店舗前と地図 前で待ち受けており，ほかの 2 台にローミングパスが割り当て られている状態を示している.

各移動経路には，タスクに応じた優先順位が設定される．優 先度の低い夕スクの移動経路は, 優先度の高い夕スクの移動経 路を迂回するように計算される。移動経路の優先順位は，1.ア プローチタスク， 2 . 店舗への誘導タスク， $3 \sim 5$. 特定場所への

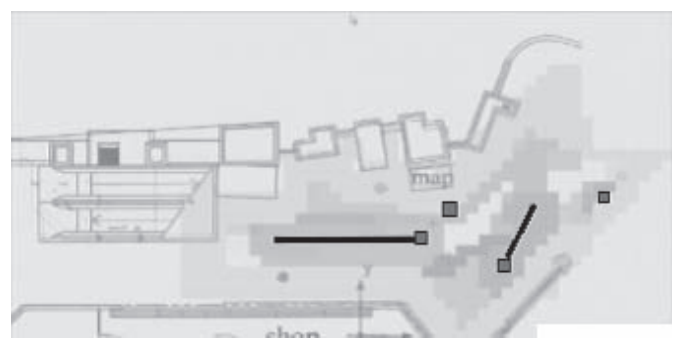

Fig. 5 Example of path information
佐 竹聡石黒浩萩田紀 博

移動タスク（地図・店舗・バッテリー充電タスク），6．ローミ ングタスクとした（Table 1).

移動経路を受け取ったロボットは，自律的に移動を開始する． 移動経路は，環境センサから取得されたロボットの位置や人々 の位置が変化した場合に，自動的に再計算される。地図や店舗 前, アプローチ対象の人位置など，特定の場所へ移動する経路 を計算する際には，最短経路法をグリッド上に分割された空間 に対して適用し，移動経路の計算を行った。このとき，人の周 辺と他ロボットの周辺, および壁から $1[\mathrm{~m}]$ の安全領域を設定 し，その領域を移動経路の計算には用いないように設定した。

4.3 ロボット間連携シナリオ調整機構（Scenario coordinator)

本研究では, 特定店舗への誘導を行うタスクにおいて, 状況 に応じて 2 台のロボットが連携するように設計を行った。ロボッ 卜間連携シナリオ調整機構は，この連携を実現するために，店 舗への誘導タスクがアサインされた 2 台のロボットに対して, P2P のネットワーク通信を確立するための IP アドレスやポー トなどの情報を送信する。ロボットが実際に連携するための詳 細は5.2.3 項に記述するが, 各ロボットはこの情報を利用して 相互に動作タイミングの調整を行う.

なお，連携を行う対象となるロボットが存在しない場合（す でに店舗前で待ち受けているロボットが他のユーザと対話をし ている，店舗前で待ち受けているロボットがそもそも存在しな い, 等) には, タスク調整機構が店舗への誘導タスクを 1 台の ロボットにのみアサインするため, この機構は動作を行わない， つまり, この機構は, 店舗への誘導タスクが 2 台のロボットに アサインされた場合にのみ動作を行う.

\section{5. ロボットシステムの実装}

ロボットは, 環境センサから得られた位置情報や予測された 行動情報を利用して，人々へのアプローチや，特定の場所で人々 を待ち受けて情報提供を行うデバイスとして利用される．プラッ トフォームから割り当てられたタスクに基づいて，ロボットは 半自律的に人々との対話を行う.

\section{1 ロボットハードウェア：Robovie}

我々は, 上述したタスクを実行し, 実環境下で人々にサービ ス提供を行うロボットとして, 移動可能なコミュニケーション ロボット「Robovie」を利用する [18]. Robovieは, ATRで開 発された，人間らしい外見の上半身を持つロボットである．2 台 のカメラと 1 台のスピーカから構成される顔, 2 本の腕，およ び台車による移動機構を備えている $($ Fig. 6). 身長は $120[\mathrm{~cm}]$ であり，重さは $40[\mathrm{~kg}]$ である。両腕に各 4 自由度，首に 3 自 由度を持ち，様々な身体動作が可能である。

移動機構には，ActiveMedia 製の Pioneer 3-DX を用いてい る。環境内の人々の移動速度や安全性を考慮し, 最大移動速度 は $2.5[\mathrm{~km} / \mathrm{h}] （ 700[\mathrm{~mm} / \mathrm{second}] ） に$ 設定した。障害物を検出 するための距離センサとして，移動台車に Hokuyo URG-04LX LRF を取り付けた。このセンサを用いることで，環境センサで は検出できない $85[\mathrm{~cm}]$ 未満の障害物を検出し, 安全に停止で きる。

ロボットの発話音声は、コーパスベースドな音声発話システ 


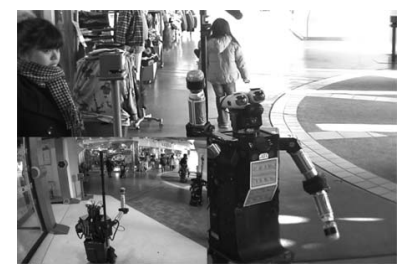

(a)

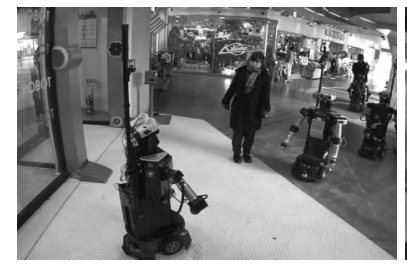

(c)

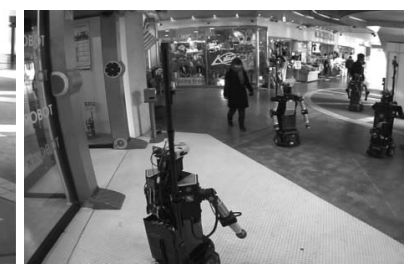

(b)

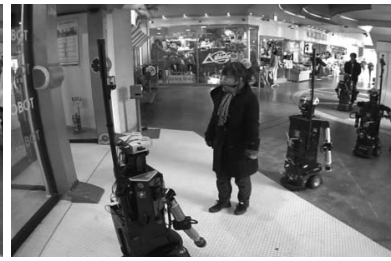

(d)
Fig. 6 Scenes of collaboration with two robots

ムによって生成される音声を利用した [19]. 身体動作の制御や ロボットに備えつけられたタッチセンサ等の情報処理は, 胴体 内部に設置された CPU で行う。無線 LAN により，プラット フォームや環境センサと通信する機能を備えている。 バッテリー を用いることで 1 時間弱の連続稼働が可能であり，またバッテ リーをホットスワップ形式で 5〜10 分程度の時間で交換するこ とが可能である.

\section{2 ロボットによるタスク実行処理}

\section{2 .1 シナリオ制御機能 (Scenario controller)}

シナリオ制御機構は, タスクに応じてあらかじめ記述された ビヘービアとよばれる状況依存モジュール [18] の遷移を実行す る。ビヘービアの遷移はエピソードルールとよばれるルールに よって記述されており, 環境センサの情報や音声認識結果によっ てビヘービアの遷移を変化させる。例えばロボットが「道案内 のオファー」ビヘービアを行った際の音声認識の結果が「トイ レ」であった場合には,「トイレへの道案内」ビへービアが実行 される.

これらの機能を用いて, Robovie は基本的に自律動作を通じ て人々と対話を行う. 例えばロボットが人にアプローチする際 には, 自律的に移動してアプローチの対象へ近づき, 一定の距 離以下まで接近したあとに会話を開始する。ささらに, 対話を行っ ている際には, 人と自身の位置関係を考慮し, 人の方へ体を向 けるなどの動作を行う。道案内動作は, 目的地までの道順を発 話と指差し動作 [20] を用いて行う. 指差しを用いた道案内動作 は，商業施設内の 70 箇所以上の施設を案内できるように用意 した。

\subsection{2 ナビゲーション機能 (Navigation controller)}

タスクがロボットに割り当てられると, ナビゲーション機能 はネットワークロボットプラットフォームの移動経路調整機構 と通信を行い, 移動経路の取得を行う. 取得した移動経路に基 づいて, ナビゲーション機能はロボットの前進速度や回転速度 の制御を行い, ロボットを移動させる。

ロボットの自己位置推定は, 環境センサから取得された人の 位置情報に加えて, ロボット自身が持つ自己位置情報と移動軌跡
の時系列変化を用いて行う [15]. 詳細は文献 [15] に示すが, カ ルマンフィルタを用いてロボットの回転方向軸の誤差を減少さ せることで，精度のよい自己位置同定を行っている.

5.2.3 ロボット間通信機能 (Cooperation controller)

上述した連携による店舗への誘導タスクを，2台のロボット を用いて自律的に行うために，ロボット間通信機能を実装した。 複数のロボットがタイミングを調整して連係動作を行うために， 過去に開発されたロボット連携を実現するためのスクリプト言 語を改良した $[21]$. ロボットはあらかじめ記述されたスクリプ 卜言語を解釈し，2台のロボットが $\mathrm{P} 2 \mathrm{P}$ で連携を取りながら言 語で記述された動作を行う

Fig. 6 に， 2 台のロボットが連携して店舗誘導・説明サービス を行っている場面を示す。ある人物がロボット A に店舗への誘 導を依頼した場合に，ロボット A はネットワークロボットプラッ トフォームに連携可能なロボットが存在するかどうかのリクエ ストを送る。このとき，ロボット B がすでに店舗前で待ち受け るタスクをアサインされており，かつ対話状態ではなかったた め，ロボットBが連携の対象としてアサインされた（Fig. 6-a). ロボット $\mathrm{A}$ はロボット $\mathrm{B}$ との連携を開始し, 店埔前への誘導 を開始する（Fig. 6-b）。このとき，ロボットAは「じゃあ，あ とはよろしくね」とロボット B に向けて発話を行い, ロボット B は「はーい, 了解しました。 じゃあ, お店の説明をするから， お客さんはもう少し前に来てね」などと発話し, 説明を開始す る、その後, ロボット $\mathrm{A}$ は移動を開始し, 別の夕スクを実行す る（Fig. 6-c）。ロボット B は引き続き店舗の説明を行い，店舗 内を訪れるように推薦を行う (Fig. 6-d).

\section{3 複数ロボットの遠隔操作システム}

本研究では, オペレータがロボットの音声認識機能を代替す る. 過去の研究では, 実験室環境内では 75 デジベルの雑音環 境下において $92.5 \%$ の認識率を実現する音声認識システムが, 駅構内などの日常環境下で一般の人々に対して音声認識を行っ た場合には， $21.3 \%$ で認識精度となったことが報告されてい る [22]. 本研究で対象とする商業施設においても, 同様の問題に よる音声認識精度の低下が予測され, 円滑な対話が困難になる と考え, 後述するオペレータによる音声認識機能代替を行った。

ロボットの遠隔操作には，環境センサの情報とロボットの対 話状態を表示する遠隔操作用インターフェースを用いた [23]. イ ンターフェースを通じて, オペレータは各ロボットから取得さ れた音声や画像を確認できる。また，ビへービアごとに定義さ れた音声認識結果の候補となる単語リストがオペレータに提示 される，オペレータが音声を参考にリスト内の単語を選択する ことで，その単語が音声認識結果としてロボットに送信される。 例えば,「どこかに案内してあげようか？」と問いかけるビへー ビアは，音声認識結果の候補として「トイレ」「駅」「いらない」 などの単語リストを持つ.

\section{6. フィールド実験}

本研究では, 道案内や情報提供, 店舗の推薦や誘導といった, 比較的シンプルなロボットサービスを題材に, 開発したシステム の有効性を検証するフィールド実験を行った，商業施設内で連携 してサービスを提供するためのロボットとして，4台の Robovie 


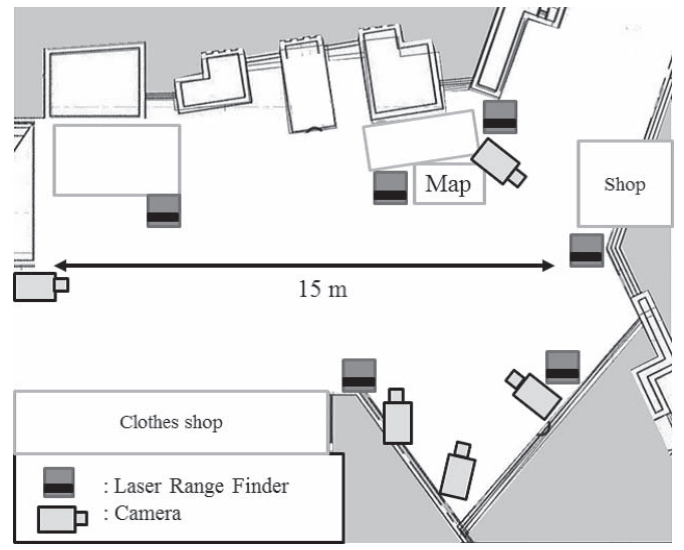

Fig. 7 Map of the mall

を用意した、ロボットが 4 台存在することで, 環境内での待ち 受けタスクを行うと同時に, 複数台のロボットによるローミン グタスクの実行が可能となる, この実験を通じて, 開発したシ ステムが 4 台のロボット間でタスクなどの調整を正しく行うこ とができたか，またその調整に基づいて活動したロボットが人々 にどのように評価されたかを検証する。

\section{1 実験設定}

本実験は, 2009 年 2 月に, ユニバーサルスタジオジャパン (USJ) の入り口付近にあるショッピングモールの通路で行われ た. Fig. 7 に, 実験環境の俯瞰図と, 設置した LRF およびカ メラの位置を示す，環境内を利用する人々の多くは，家族やカッ プル，観光者であった，人々は，ロボットと自由に対話するこ とができた。

昼間の時間帯において, 人々は昼食や買い物, およびUSJに 向かって移動するために，主に左から右方向に移動していた。 夜間の時間带に扔いては, 人々は夕食や買い物, 抢よび駅に向 かって締路につくために, 主に右から左方向に移動していた，そ のため実験では, 昼夜の利用者数の違いや数の偏りを避けるた め, 昼間と夜間においてそれぞれ 3 時間，合計 6 時間の実験を 行った.

実験では， 1 人のオペレータが 4 台の遠隔操作を行う。また， 安全を確保するため, 1 人のスタッフが環境内に滞在した. なお， この実験は研究目的にのみ利用するという条件の下で, ショッ ピングモールの管理者の承認を得て行われた，この手続きにつ いては，所内の倫理審査委員会により承認ずみである。

\section{2 実験結果}

\subsection{1 システムの動作例}

はじめに, 我々が開発したシステムが実環境でどのようにロ ボットへタスクがアサインされ，どのような対話が観察された かについて記述する。

基本的に, 2 台のロボットに対してローミングタスクがアサ インされ，あとの 2 台には地図前での待ち受けタスクと店舗前 での待ち受けタスクがそれぞれアサインされた，環境内に，局 所行動が「ゆっくり歩く」「止まる」人物が存在した場合には, ローミングタスクを行っているロボットにアプローチタスクが アサインされ，アプローチが成功した場合には情報提供などの 対話が行われた。また，待ち受けタスクを行っているロボット
Table 2 Number of people in each category

\begin{tabular}{|c|c|c|}
\hline & Four robots & No robots \\
\hline Passing & 2,365 & 2,139 \\
\hline Watching the shop & 31 & 19 \\
\hline Entering to the shop & 15 & 0 \\
\hline
\end{tabular}

の周辺で局所行動が「止まる」と予測された人物が存在した場 合には，ロボットはその人物に対して話しかけを行った，待ち 受けタスクがアサインされているロボットに, バッテリーの充 電や店舗誘導タスクがアサインされた際には，ローミングタス クがアサインされている別のロボットに待ち受けタスクがアサ インされた。

実験では, 合計 2,411 人の人々が環境内を通過し, そのうち 414 人がロボットとの対話を行った，実験では, 多くの人々が ロボットとの長時間の対話は行わず，むしろロボットがどのよ うな対話や反応を行うのかを試すような，簡単な対話を行った， 例えば，ロボットが握手を人々に求めた場合に，人々は握手を 行った後にさよならなどと発話して立ち去るなどの, 数十秒程 度の対話が頻繁に観察された。一方, 興味深い対話が観察され た事例としては，実際に道に迷った人々がロボットへ特定のレ ストランや服飾店, 契煙所などへの道案内を依頼し, ロボット への道案内に㧍礼を言ってその場へと訪れる場面が観察された。 また，ロボットの店舗誘導を受けて実際に店舗内を訪れる人や， 店舗を観察する人の存在が観察された。

\subsection{2 ロボットによる宣伝効果の検証}

本実験における，ロボットによる店舗の推薦効果を検証する ために, 店舗の入り口から $3[\mathrm{~m}]$ 以内の距離で, 3 秒以上店舗を 観察していた人をカウントした，その結果，環境内を通過した 人々のうち， 46 人が推薦された店舗に興味を持ち，46 人のう ち 15 人が実際に店舗内へと足を運んでいた。

さらに，ロボットの有無による店舗の推薦効果を検証するた めに, 比較としてロボットが存在しない条件で 6 時間の観察を 行った？その結果， 2,158 人の人々が環境内を通過し，19人の 人々が店舗に興味を持ったが, 店舗内を訪れた人の数は 0 人で あった. Table 2 に、ロボットが存在する条件と、ロボットが 存在しない条件で計測された人々の数を示す.

ロボットが存在する条件と存在しない条件に対して, カイ 2 乗 検定を行った結果, 条件間で有意差が見られた $(\chi 2(2)=15.258$, $p<0.001)$. 残差分析を行った結果, ロボットが存在する条件 では店舗内へと足を運んだ人々が有意に多く $(\gamma=3.7, p<$ 0.01）、ロボットが存在しない条件では店舗内へと足を運んだ 人々が有意に少なかった $(\gamma=-3.7, p<0.01)$. ただし, 環 境内を通過した人々の数は, ロボットが存在しない条件が優位 に多く $(\gamma=2.9, p<0.01)$, ロボットが存在する条件が優位 に少なかった $(\gamma=-2.9, p<0.01)$. な押, 店埔に興味を持っ た人々の数に対しては, 有意な差は得られなかった.

\subsection{3 夕スク調整機構の動作検証}

タスク調整機構が正しく動作したかを検証するために，各夕 スクがロボットに正しくアサインされていたかどうかの計測を 行った，計測には，記録されたビデオ，ロボットの行動履歴，お よびオペレータによるロボットの操作履歴を用いた. 
まず,アプローチタスクのアサインに関する検証を行った フィールド実験中，各ロボットにアサインされたアプローチタ スクの合計は, 2,080 回であった。タスクのアサインは, 基本 的に, アプローチ対象に最も近いローミングタスクを実行して いるロボットに対して行われた。ただし，タスクのアサインが 失敗した事例として，1 人に対して複数台のロボットが同時に アプローチを行うケースが 5 回，ロボットが他のロボットにア プローチを行うケースが 1 回発生していた。アサインの失敗が 起きた主な理由は，人追跡システムによる誤認識によって，す でにアプローチずみの人に割り当てられたID が変化して別の 人と認識される, またはロボットが人として認識されたために 発生した。ただし, そのエラー回数は全体のタスクアサイン回 数に比べて十分に少なかったと考える.

次に，地図前と店舗前の待ち受けタスクが正しくアサインさ れたかを検証した，地図前と店舗前での待ち受けタスクがアサイ ンされた時間の割合を計測した結果，地図前では 90.6\%（326.4 分), 店舗前では $94.0 \%$ (338.5 分) の時間, それぞれの場所で 待ち受けタスクがアサインされたロボットが存在していた。ロ ボットが各地点で待ち受けていなかった時間の主な理由は, 待ち 受けタスクがアサインされて移動を開始したロボットに人々が 話しかけ，対話タスクが開始されてしまい，待ち受けるべき場所 にロボットが到達できなかったためであった，そのような場合に は，別のローミングタスクを行っているロボットに待ち受けタス クが再度アサインされた。結果的に $90 \%$ 以上の割合で待ち受け タスクが実行されており，開発したシステムが設計通りに正しく 待ち受けタスクをアサインしていたことが示されたと考える.

次に，店舗への誘導時に連携タスクが正しくアサインされた かを検証した。店舗から離れた場所において，ロボットが対話 している人からの店舗誘導の依頼を受けた回数は 6 回であった. 店舗前の待ち受けタスクがアサインされたロボットが存在した 状況はそのうち 3 回存在し, そのすべての回で 2 台による連携 が行われた。それ以外の状況では，すべての回で 1 台のロボッ トによる店舗誘導が行われた。つまり，連携に関するタスクア サインはすべて正しく行われた.

最後に，バッテリー充電タスクが正しくアサインされた回数 を計測した。実験中，ロボットの残バッテリー容量に応じて合 計 16 回のバッテリー充電タスクが行われ，ロボットはバッテ リー切れを起こすことなく動作を継続することができた.

これらの結果から, タスク調整機構を用いることで, 状況に 応じてサービスを行うロボットを切り替える, サービス内容そ のものを切り替える, 複数台のロボット連携による情報提供, な どの，ロボット間のタスク調整を正しく実現できたことが示さ れたと考える.

\subsection{4 移動経路調整機構の動作検証}

移動経路調整機構が正しく動作したかを検証するために，ロ ボット同士の移動経路が干渉を行い, ロボットが静止してしまっ た回数を計測した。その結果，6時間でロボットの移動経路は 7 回の干涉が発生した。この現象が起きた原因として, 人追跡 システムが混雑などの要因によってロボットを人として誤認識 してしまい，ロボットの自己位置が正しく認識されなかったた めであった。ただし，6時間の動作で発生した干渉の回数とし

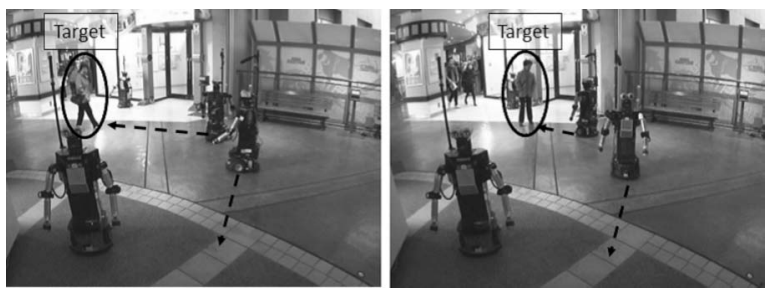

Fig. 8 Example of approaching and roaming behavior

ては，システムを運用する中で十分に少ないものであったと考 える。なお，この現象が発生した場合にのみ，オペレータは口 ボットの移動機能を遠隔で制御し, 問題を解決した.

Fig. 8 に, 複数ロボットの移動経路の調整が正しく行われた場 面の例を示す．環境センサによって予測された局所行動が「ゆっ くり歩く」（図中の丸で囲まれた人物）であった場合に，夕ス ク調整機構は図中の右から 2 番目のロボットに対してアプロー チタスクを設定した。その際に，タスク決定機構は一番右のロ ボットに対してローミングタスクを引き続き設定した。その結 果, 移動経路調整機構は一番右のロボットの移動経路を手前側 に変更し，アプローチの邪魔にならないように設定された。そ の結果, 右から 2 番目のロボットが「ゆっくり歩く」人にアプ ローチして対話を開始している際に，いちばん右のロボットが 対話の邪魔にならないように手前側に移動することができた。

これらの結果から，移動経路調整機構を用いることで，ロボッ 卜同士が安全に移動し，タスクを実行できることが示されたと 考える。

\subsection{5 夕スク連携調整機構の動作検証}

タスク連携調整機構が正しく動作したかを検証するために, 店舗誘導タスク時に正しくロボットが連携したかどうかの回数 を検証した，2台のロボットによる連携タスクがアサインされ た 3 回のうち, すべての回において 2 台のロボットは正しく連 携を行い, Fig. 6 に示したように，2台間で発話や動作の夕イ ミングを調整して店舗への誘導タスクを行っていた。これらの 結果から，タスク連携調整機構を用いることで，ロボット同士 のタスク連携が実現できたと考える。

\subsection{6 ロボットに対する印象評価}

実験結果から，開発したシステムがほとんどの状況において タスクをロボット間で正しく調整できたことが示された，次に 我々は，システムによってアサインされたタスクを実行したロ ボットに対して，実際に対話を行った人々はどのような印象を 持ったかについて検証した。

検証のために，ロボットと対話を行った人々へのアンケート 調査を行った。アンケートで用いた三つの質問項目を以下に示 す. 項目の評価は, 1 (低評価) 〜 (高評価) の 7 段階とした

・ロボットの話した内容への興味（Interesting）

・ロボットの有用性（Effectiveness）

・ロボットの楽しさ (Impression)

実験において取得したアンケート数は 103 であった。各項目 の平均と標準誤差を, Fig. 9 に示す。アンケートの結果から, す べての項目において平均值以上の評価が得られた。つまり，開発 したシステムによってアサインされたタスクを実行したロボット 


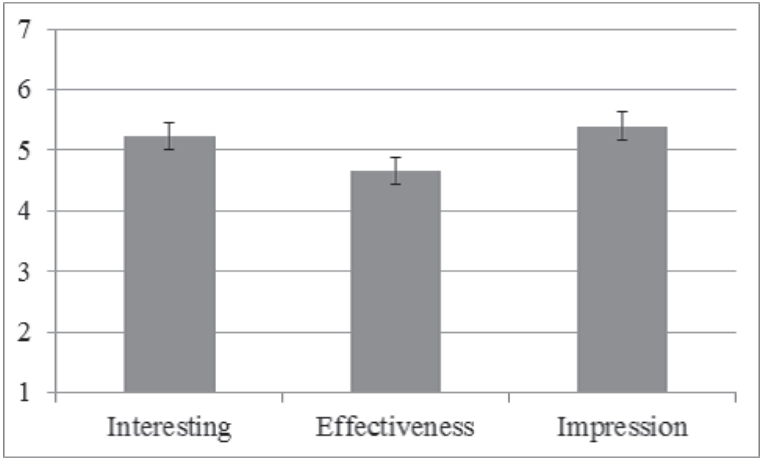

Fig. 9 Questionnaire results

に対して，対話した人々は好意的な評価を持ったことが示された

\section{7.おわりに}

本研究では, 商業施設に扔いて複数のロボットが連携して人々 へのサービス提供を実現する, ネットワークロボットロボット システムの開発を行った。開発したシステムは, 環境センサ, 複 数の案内ロボット, 抢よびネットワークロボットプラットフォー ムから構成される. 環境センサは, 環境内に存在する人々の行 動推定㧍よびロボットの位置推定を行う. ロボットは基本的に 自律動作を行うが, 対話時にはオペレータによる音声認識機能 の代替を利用して道案内や店舗誘導などの情報提供サービスを 行う。ネットワークロボットプラットフォームは, 環境センサ やロボットから得られる情報に基づいて, 複数ロボット間の夕 スクや移動経路，ロボット間連携の調整を行う.

開発したシステムの有効性を検証するため, 商業施設に㧍い て 4 台のロボットを利用したフィールド実験を行った. 実験で は 2,411 人が環境内を追加し，414 人がロボットとの対話を行っ た、ロボットが誘導した店舗にはそのうち 46 人の人々が興味を 示し, 15 人の人々が店舗内を訪れていた.

実験結果を通じて, 商業施設のような日常環境において, 複 数ロボットが連携して一般の人々へ情報提供サービスを実現す るシステムの有效性を検証した。 具体的には, 開発したシステ ムを用いることで, 状況に応じてサービスを行うロボットを切 り替える, サービス内容そのものを切り替える, 複数台のロボッ 卜連携による情報提供, などのロボット間の調整を正しく実現 できることを確認した，さらに，アンケートの結果から，商業 施設内で活動するロボットが, 人々に対して好意的な印象をも たらしたことを示した

謝 辞 本研究に参加していただき，様々なご支援をしてい ただいた住商アーバン開発株式会社の管理スタッフの皆様に厚 く感謝申し上げます。 また, 実験にご協力いただいた ATR 知 能ロボティクス研究所の秋本氏, 宮下氏, 胡桃沢氏に厚く感謝 申し上げます。本研究は, 総務省の研究委託により実施したも のである.

\section{参 考 文 献}

[1] W. Burgard, et al.: "The interactive museum tour-guide robot," Proc. of National Conference on Artificial Intelligence, pp.11-18, 1998.
[2] R. Siegwart, et al.: "Robox at Expo.02: A Large Scale Installation of Personal Robots," Robotics and Autonomous Systems, vol.42, no.3, pp.203-222, 2003.

[ 3 ] R. Gockley, J. Forlizzi and R. Simmons: "Interactions with a Moody Robot," HRI2006, pp.186-193, 2006.

[4] T. Kanda, T. Hirano, D. Eaton and H. Ishiguro: "Interactive Robots as Social Partners and Peer Tutors for Children: A Field Trial," Human Computer Interaction, vol.19, no.1-2, pp.61-84, 2004.

[ 5 ] 小林亮博, 上田博唯, 佐竹純二, 近間正樹, 木戸出正継： “家庭内工 ビキタス環境における対話ロボットの実稼動実験と対話戦略の評価”, 情報処理学会論文誌, vol.48, no.5, pp.2023-2031, 2007.

[6] H. Kozima, C. Nakagawa and Y. Yasuda: "Interactive robots for communication-care: A case-study in autism therapy," IEEE International Symposium on Robots and Human Interactive Communication, pp.341-346, 2005.

[ 7 ] F. Tanaka, A. Cicourel and J.R. Movellan: "Socialization between toddlers and robots at an early childhood education center," Proc. of the National Academy of Sciences of the USA, vol.104, no.46, pp.17954-17958, 2007.

[8] L. Carlone, et al.: "Rao-Blackwellized Particle Filters Multi Robot SLAM with Unknown Initial Correspondences and Limited Communication," ICRA2010, pp.243-249, 2010.

[9] X. Zheng and K. Sven: "Negotiation with Reaction Functions for Solving Complex Task Allocation Problems," IROS2009, pp.4811-4816, 2009.

[10] H.M. Gross, et al.: "TOOMAS: Interactive Shopping Guide Robots in Everyday Use - Final Implementation and Experiences from Long-term Field Trials," IROS2009, pp.2005-2012, 2009.

[11] HONDA「ASIMO」, http://www.honda.co.jp/ASIMO/

[12] A. Sanfeliu, N. Hagita and A. Saffiotti: "Network Robot Systems," Special Issue: Network Robot Systems, Robotics and Autonomous Systems, pp.793-797, 2008.

[13] Research study for the scope of the strategy map of robotics technology, 2005. (Available at http://www.nedo.go.jp/ database/index.html, with index code 100007875) (in Japanese).

[14] T. Kanda, et al.: "Who will be the customer? A social robot that anticipates people's behavior from their trajectories," UbiComp2008, pp.380-389, 2008.

[15] D.F. Glas, et al.: "Simultaneous People Tracking and Localization for Social Robots Using External Laser Range Finders," IROS2009, pp.846-853, 2009.

[16] V. Vapnik: The Nature of Statistical Learning Theory. Springer, 1995.

[17] 佐竹聡, 神田崇行, Dylan F. Glas, 今井倫太, 石黒浩, 萩田紀博: “対話 ロボットの人間へのアプローチ方法一対話ロボットの対話開始に対す る戦略—”, 日本ロボット学会誌, vol.28, no.3, pp.327-337, 2010.

[18] T. Kanda, H. Ishiguro, M. Imai and T. Ono: "Development and Evaluation of Interactive Humanoid Robots," Proceedings of the IEEE, vol.92, no.11, pp.1839-1850, 2004.

[19] H. Kawai, T. Toda, J. Ni, M. Tsuzaki and K. Tokuda: "XIMERA: A New TTS from ATR Based on Corpus-Based Technologies," Proc. of Fifth ISCA Workshop on Speech Synthesis, pp.179-184, 2004.

[20] O. Sugiyama, et al.: "Humanlike conversation with gestures and verbal cues based on a three-layer attention-drawing model," Connection science, vol.18, no.4, pp.379-402, 2006.

[21] D. Sakamoto, et al.: "Humanoid Robots as a Broadcasting Communication Medium in Open Public Spaces," International Journal of Social Robotics, vol.1, no.2, pp.157-169, 2009.

[22] M. Shiomi, D. Sakamoto, T. Kanda, C.T. Ishi, H. Ishiguro and N. Hagita: "A Semi-autonomous Communication Robot -A Field Trial at a Train Station-," HRI2008, pp.303-310, 2008.

[23] D.F. Glas, T. Kanda, H. Ishiguro and N. Hagita: "Simultaneous Teleoperation of Multiple Social Robots," HRI2008, pp.311-318, 2008. 


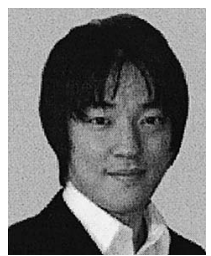

塩見昌裕（Masahiro Shiomi）

2004 年大阪大学大学院工学研究科知能 ·機能創成 工学専攻博士前期課程修了. 2007 年同専攻博士後 期課程修了. 博士 (工学). 現在 ATR 知能ロボティ クス研究所研究員としてコミュニケーションロボッ トの研究に従事，ネットワークロボット，コミュニ ケーションロボット，集団とロボットの相互作用に 興味を持つ。

(日本ロボット学会正会員)

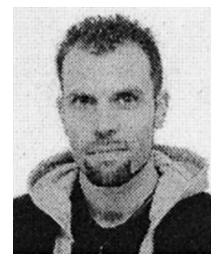

\section{Dylan F. Glas}

1997 年マサチューセッツ工科大学工学部航空宇宙 工学科, 理学部地学·大気圈学・天文学科卒業. 2000 年同大学大学院工学研究科航空宇宙工学宇宙システ 厶工学専攻修士課程修了. 現在 ATR 知能ロボティ クス研究所研究員としてコミュニケーションロボッ トの研究に従事。ネットワークロボットシステム 遠隔操作, 人間と機械との相互作用, ユビキタスセンサに興味を持つ.

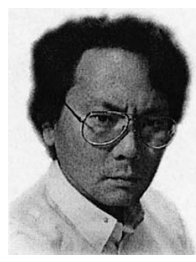

\section{石黒 浩 (Hiroshi Ishiguro)}

1991 年大阪大学大学院基礎工学研究科物理系専攻 博士課程修了. 工学博士. 同年山梨大学工学部情報 工学科助手, 1992 年大阪大学基礎工学部システム 工学科助手. 1994 年京都大学大学院情報学研究科 社会情報学専攻助教授. 2001 年和歌山大学システ ム工学部情報通信システム学科教授. 現在大阪大学 大学院基礎工学研究科・システム創成専攻教授，ATR 知能ロボティ クス研究所第二研究室客員室長. 視覚移動ロボット, 能動視覚, パノ ラマ視覚, 分散視覚に興味を持つ。（日本ロボット学会正会員）

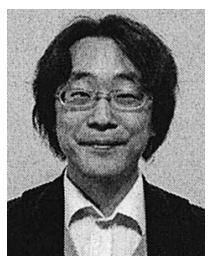

\section{神田崇行（Takayuki Kanda）}

1998 年京都大学工学部情報工学科卒業. 2000 年 同大学大学院情報学研究科社会情報学専攻修士課 程修了. 2003 年同専攻博士課程修了. 博士（情報 学). 現在 ATR 知能ロボテイクス研究所上級研究 員. ヒューマンロボットインタラクション, 特にロ ボットの自律対話機構や社会的能力, 人間型ロボッ トの身体を利用した対話に興味を持つ。（日本ロボット学会正会員）

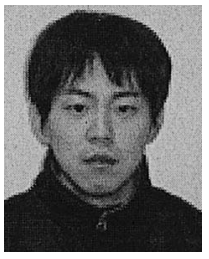

佐竹 聡 (Satoru Satake)

2003 年慶應義塾大学理工学部情報工学科卒業. 2005 年同大学大学院開放環境科学専攻前期博士課程修了. 博士 (工学). 現在 ATR 知能ロボティクス研究所研 究員. ヒューマンロボットインタラクション, ネット ワークロボットシステム，ヒューマンインターフェ イスに興味を持つ。（日本ロボット学会正会員）

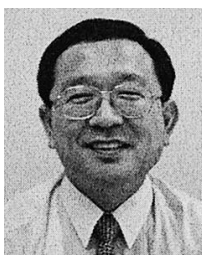

萩田紀博（Norihiro Hagita）

1978 年慶應義塾大学大学院工学研究科電気工学専 攻修士課程修了. 同年日本電信電話公社（現 NTT） 武蔵野電気通信研究所に入所. 文字認識や画像認識 などの研究に従事. NTT 基礎研究所などを経て, 現在 ATR 知能ロボティクス研究所所長. 工学博士 IEEE，電子情報通信学会，情報処理学会，人工知 能学会各会員.

（日本ロボット学会正会員） 